\title{
How well established is research on organised crime in Germany?
}

\author{
Klaus von Lampe and Susanne Knickmeier ${ }^{1}$
}

\section{Introduction}

The study of organised crime has developed into a distinct academic (sub)discipline over the past two or three decades. However, there are considerable variations across countries. In some places, such as the Netherlands, research on organised crime is well established, while in other places it appears to be a much more marginalised endeavour, at least when assessed on contributions to the international scholarly debate. Germany is a case in point. For example, a cursory review of the programs of the annual meetings of the American Society of Criminology (ASC) and European Society of Criminology (ESC) reveals that presentations by criminologists from Germany relating to the topic of organised crime are rare although otherwise there is a strong German presence at these conferences. Similarly, there are only few organised crime-related contributions by German-based scholars to journals such as Crime, Law and Social Change, Global Crime, and Trends in Organised Crime. For example, for every contribution from Germany between 2008 and 2017 there were five times more contributions from scholars based in the Netherlands. In Crime, Law and Social Change, no organised crime-related articles by German-based scholars can be found in this 10-year period at all compared to 12 organised crime-related articles by authors from the Netherlands. In Global Crime, there was one organised crime-related contribution from Germany and seven from the Netherlands, and in Trends in Organised Crime, German-based authors accounted for only seven articles compared to 22 articles authored by Dutch-based authors.

1 Klaus von Lampe is professor of criminology at the Berlin School of Economics and Law, Berlin, Germany. Susanne Knickmeier is researcher at the Max Planck Institute for Foreign and International Criminal Law, Freiburg, Germany. 
The purpose of this chapter is to assess the state of organised crime research in Germany and to examine whether the impression of a general neglect of the study of organised crime is a misconception.

This chapter is divided into two main parts. The first part provides a brief overview of the situation of organised crime in Germany as it presents itself in official and media accounts. As it becomes evident, Germany has very good reasons for being concerned about the organisation of crimes and criminals within its borders, so the lack of research on organised crime cannot be explained by the absence of appropriate objects of study. The second part describes findings of a systematic analysis of the output of researchers based in Germany who study organised crime. This includes an inventory of research projects, dissertation projects and academic publications on issues relating to organised crime over a period of some ten years. The focus is on the continuity and consistency of lines of research rather than on questions of quality or content. The aim is to illustrate how well the study of organised crime is established institutionally, namely with regard to specific academic disciplines and institutions, and with a view to its funding. No attempt is made to systematically review the substance of the research and to elucidate what it might reveal about the situation of organised crime in Germany. The reason for this omission is twofold. First, a considerable share of the pertinent scholarship does not address the situation in Germany but rather the situation elsewhere in the world, and second, as will be shown in more detail below, the study of organised crime in Germany is far too fragmented to present an even remotely coherent picture. Against this backdrop, this chapter concludes with a discussion of how organised crime research in Germany can potentially be strengthened and how scholars based in Germany can achieve a greater impact on the international academic debate on organised crime.

\section{The current situation of organised crime in Germany}

Law enforcement agencies and the media in Germany regularly report on manifestations of organised crime, broadly defined. One focus is on organised criminal activities and illegal markets. Another focus is on criminal groups and networks. A third major concern is with criminal milieus that 
reportedly have come under the influence of powerful underworld figures and underworld alliances.

\section{Organised criminal activities}

If organised crime is understood in terms of organised criminal activities, two broad areas have to be distinguished: illegal markets characterised by seller-buyer relations, and the organised commission of predatory crimes involving perpetrators and victims. Not least because of a large and growing population (82,79 million in 2017), ${ }^{2}$ Germany is an important market place for illegal goods and services. This is particularly true for the illegal drug trade, although in terms of per-capita consumption, Germany tends to rank only in the middle or towards the bottom among European countries (EMCDDA, 2017).

Most of the drugs consumed in Germany (cannabis, cocaine, heroin and amphetamine) originate from other European and non-European countries. The country also functions as a transit country for drug smuggling (Europol 2013). In addition, Germany is the leading European country by sales volume in the distribution of drugs via the darknet (EMCDDA, 2017: 20). With respect to the production of drugs, however, Germany is only of marginal relevance, with small shares in the manufacturing of amphetamines and the cultivation of cannabis (Bundeskriminalamt, 2016: 5-6).

Apart from illegal drugs, Germany ranks high among consumer countries for illegal cigarettes. In terms of overall volume, Germany is in fourth place behind France, Poland, and the UK. However, according to a study sponsored by the tobacco industry, the consumption of smuggled and counterfeit cigarettes has declined considerably in recent years, dropping from a share of $11,5 \%$ of the overall cigarette market in 2012 to only 5,2\% in 2016 (KPMG, 2017: 76).

Other illegal markets that have repeatedly been mentioned in connection with organised crime and the crime situation in Germany include the trade in counterfeit brand products, counterfeit medicine, protected species, protected cultural artefacts, and guns, human trafficking and human smuggling, as well as illegal gambling, in particular illegal sports betting.

2 https://de.statista.com/statistik/daten/studie/2861/umfrage/entwicklung-dergesamtbevoelkerung-deutschlands/ (7 February 2019) 
Finally, Germany is considered a hotbed for money laundering (Bülles, 2013, p. 249).

The supply of illegal goods and services is not the only facet of the organised crime landscape in Germany. In fact, a lot of attention in the German debate on organised crime has been paid to predatory crimes, including such offences as motor vehicle theft (Bundeskriminalamt, 2017), serial residential burglary (Backes et al., 2016) and pickpocketing (Gögelein, 2017). A substantial part of these crimes is attributed to transnationally mobile offender groups from Eastern Europe (Winter, 2015). Other areas of organised predatory crimes with a remarkable extent of damages, estimated at several billion Euros annually, include, for example, cybercrime (Berg and Maßßen, 2017) and fraud against the welfare system (Dowideit, 2017).

\section{Offender structures}

Referring to the organisation of crimes it cannot automatically be considered that the respective perpetrators are also 'organised'. For example, the existence of illegal markets implies a web of buyer-seller relations across different levels of the illicit supply chain. However, it remains an open question to what extent more integrated and coherent offender structures are involved. This open question applies, on one hand, to the presence of foreign criminal organisations on German soil, and on the other hand, to indigenous criminal structures (Kamstra, 2014; Paulus, 2015; Schulz, 2012).

The federal German police agency Bundeskriminalamt (BKA) prepares an annual organised crime situation report which includes an assessment of the degree of organisation of offender groups under investigation by German law enforcement agencies at the state and federal levels. For each offender group, a score ("organised crime potential") on a scale from 0 to 100 is calculated based on a weighted list of 50 indicators which range in value from 1,17 to 4,35 . The highest ranked indicators are 'hierarchical structure', followed by 'international', 'an at first glance inexplicable relation of dependence or authority between several suspects', 'payment of bribes', and 'measures to launder money', while the lowest ranked indicators include 'assumed names', 're-admittance after release from prison', 'work on demand', 'disappearance of formerly available witnesses', and 182 
'use of relatively expensive or difficult to implement scientific means and findings' (von Lampe, 2004: 92). The limitations of the use of such a composite index aside, it is remarkable that only few of the detected offender groups achieve a high score. In 2017, the average organised crime potential was only 40,9 out of 100 points referring to 572 investigations (Bundeskriminalamt, 2018: 5). This is consistent with results of early research on the level of organisation of offender groups in Germany from the 1970s and 1980s. These pioneering studies concluded that the German underworld is predominantly populated by loose, network-like offender structures (Kerner, 1973; Rebscher and Vahlenkamp, 1988; Weschke and Heine-Heiß, 1990).

\section{Illegal governance}

The exposure of illegal markets, predatory crimes, and the illegal businesses running these various schemes is relatively straightforward police business. In contrast, it is much more challenging for law enforcement agencies to detect and to investigate underlying criminal power structures, given that these structures tend to be elusive and rest primarily on the perceptions and beliefs of those that are governed. However, that is difficult to determine. Accordingly, organised crime situation reports neither contain information on the territoriality and spheres of influence of criminal groups, nor on the details of how criminal power is exercised.

What can be gleaned from the annual organised crime situation reports is the small share of cases attributed to members of Italian criminal associations. In 2017, only 14 out of 572 organised crime investigations were directed against Italian mafia-type associations, including seven involving 'Ndrangheta, three pertaining to the Sicilian Cosa Nostra, and two against the Camorra (BKA, 2018: 20). Contrary to their cliché, these organisations do not automatically attain positions of power when establishing a presence abroad, but they have shown an ability to acquire territorial control at least under certain circumstances (Varese, 2011). Nevertheless, according to a recent assessment provided by the German federal government, Italian criminal associations do not occupy prominent positions in the ethnically diverse criminal landscape of Germany (Bundesregierung, 2017). 
The fact that the annual situation reports remain inconclusive regarding the existence of underworld power structures does not mean that such structures do not exist. In fact, there are numerous indicators, documented in official and media sources, which point to a consolidation and concentration of power in the German underworld, partly in the course of a historical process of the rise and fall of influential groups and alliances (see Behr, 1989; Gülay and Kuhn, 2009). At the centre of attention in the current debate on criminal power structures are so-called Arab clans. The term is applied to various large 'blood families' that originate from the TurkishKurdish-Arabic region and have settled in Germany since the 1980s. Many of the male members of these family clans have been implicated in criminal activities including theft, robbery, extortion, illegal prostitution and drug trafficking. In certain urban areas, namely Berlin, Bremen and the Ruhr region, they allegedly control entire neighbourhoods and illegal markets. If conflicts arise between different clans, self-proclaimed underworld magistrates provide dispute resolution services (Ghadban, 2018; Henninger, 2002; Wöhrle, 2017).

Sometimes, a dominating role in criminal milieus is also attributed to outlaw motorcycle clubs, for example by collecting protection payments from drug dealers (Adelsberger, 2012: 574). Against this backdrop, frequent conflicts between biker clubs are interpreted as struggles over spheres of influence and control over criminal activities (Bader, 2010; Jäger, 2012; Ziercke, 2010).

There are also claims that the influence of groups such as family clans or biker clubs extend to the legal spheres of society. This pertains primarily to the red-light sector and, more generally, the nightlife economy. Thereby, fluid boundaries appear between pure extortion, the provision of protection through illegal means, and the operation of legal security firms owned by underworld figures (Henninger and Susebach, 2005). However, there is no evidence that criminal influence has reached further to, for example, the construction sector (see Bundesregierung, 2017), in a way similar to the control acquired by Southern Italian Mafiosi in Northern Italy (Varese, 2011). 


\section{Taking stock of output of scholars based in Germany}

From even the most cursory review of official and media accounts of the crime situation in Germany it becomes clear that students of organised crime have plenty to examine and many unanswered questions. Of course, one would exaggerate and overly dramatize things by drawing parallels between Germany and, say, Italy, the United States, Russia or Mexico with respect to the scale of the problem and the degree to which underworld and upperworld are intertwined. Yet, in essence all facets of the problem of organised crime can be observed in Germany, be they in a nascent state, emerging, or fully developed. In addition, Germany provides an important research site for studies of organised crime by its crime-geographic position. When seeking to understand the major trafficking routes that start, end or transect Europe, it is difficult to ignore Germany's role. For all these reasons, one would expect to find a well-developed German tradition of research into the organisation of crimes and criminals. Indeed, in the 1970s and 1980s, Germany was at the forefront in Western Europe when it came to criminological research on organised crime, just as it was pioneering the debate on the conceptualization of organised crime (Kerner, 1973; Mack and Kerner, 1975; Rebscher and Vahlenkamp, 1988; Weschke and HeineHeiß, 1990). But what is the state of organised crime research in Germany today?

\section{Methodology}

The aim of the present analysis is to provide a rough overview of the study of organised crime in Germany over the past ten years with a view to such aspects as the volume of scholarly work, thematic foci, methodological approaches, and funding. Because of limited resources, it was not possible to extend the scope of the analysis to an in-depth, critical review of the research activities and scholarly literature. One line of inquiry relates to the scientific work, for example to what extent there is a clustering of research around specific topics and research questions, certain theoretical and conceptual approaches, or the usage of specific types of data. Another issue that is being addressed here pertains to the institutional context within 
which research on organised crime is carried out, namely regarding the academic and non-academic institutions and academic disciplines involved, and the sources of funding that are available.

This chapter is based on a project commissioned by the Forschungsforum Öffentliche Sicherheit (Research Forum Public Security) at Freie Universität Berlin, Germany. ${ }^{3}$ The project entailed taking stock of the projects pursued and publications published by scholars based in Germany between 1 January 2008 and 1 September 2017. In an effort to identify all relevant scholarly activities, a number of literature databases and internet platforms (Deutsche Nationalbibliothek, Google Scholar, Google Books, KrimDok) were searched using various terms including "organisierte Kriminalität" (organised crime), "organised crime" + "Germany," "Kriminalität" (crime), "Mafia," "Schmuggel" (smuggling), "Drogenhandel" (drug trade), "Menschenhandel" (human trafficking), and "illegal" + "Handel" (trade).

Given that the purpose of the study was to assess the state of organised crime research in Germany, only projects and publications of those scholars were included who were based in Germany at the time the project was carried out, respectively, at the time of the publication. This excludes two groups of scholars, first, German scholars based abroad, ${ }^{4}$ and, second, nonGerman scholars based outside of Germany doing research on, and writing about organised crime in Germany. The determination of the geographical location presented no methodological problems in the case of research and dissertation projects, as these tend to be clearly attached to specific institutions, and thus to specific places. It was much more challenging ascertain where authors were based at a particular point in time. Since it is not unusual for scholars to move from one academic institution to another throughout their careers, while institutional websites and other sources of information about academic affiliations are not necessarily always up-to-date. In some instances, the inclusion or exclusion of a publication rested on a determination of the most likely scenario based on available information.

\footnotetext{
3 See von Lampe and Knickmeier (2018).

4 This also applies to the first author who was based in Germany for only the first seven months of the study period, and accordingly only three of his soloauthored publications are included in the present analysis. 
The assessment of the scholarly output of researchers based in Germany encompasses a total of 285 items, including 32 research projects, 38 doctoral dissertations, and 215 academic publications. These categories are not mutually exclusive in the sense that research and dissertation projects often (but not always) lead to other academic publications.

\section{Research Projects}

For the time period under study, a total of 32 completed or ongoing research projects could be identified (see von Lampe and Knickmeier, 2018: 32-37). In this context, research projects are defined as formal research endeavours undertaken by (academic or non-academic) institutions with a defined purpose and a set time frame, irrespective of the source of funding. In other words, the analysis covers externally funded projects as well as self-funded, respectively non-funded research. PhD-dissertation projects, however, are excluded here, and included in a separate category discussed further below.

In identifying pertinent research projects, we drew, first of all, on our literature review. In addition, we searched databases and websites of research funding institutions such as the European Commission, the German Federal Ministry of Education and Research (BMBF) and the German Research Foundation (DFG) as well as the websites of research institutions that potentially carry out or participate in studies related to organised crime. These latter institutions included the Criminological Research Institute Lower-Saxony (KfN), the Centre for Criminology (KrimZ), the National Centre for Crime Prevention (NZK), the German Police University (DHPol), and the Max Planck Institute for Foreign and International Criminal Law (MPICC). Further information of completed and ongoing research projects was obtained from a review of media sources.

When examining the 32 research projects and their respective time frames it becomes immediately apparent that there has been a marked upward trend in the number of projects pursued in a given year over the past 10 years. While between 2008 and 2013 only up to seven projects were initiated, continued or completed in a given year, this number jumped to 17 in 2014 and 24 in 2015. This sharp increase can partly be explained by a new line of funding launched by the federal government (BMBF) in 2013 under the title Civil Security: Protection against Organised Crime. On the 
basis of this research program eight projects have been financed since 2014 (von Lampe and Knickmeier, 2018: 37).

Figure 1.

Research projects related to organised crime, 2008-2017*:

Thematic focus

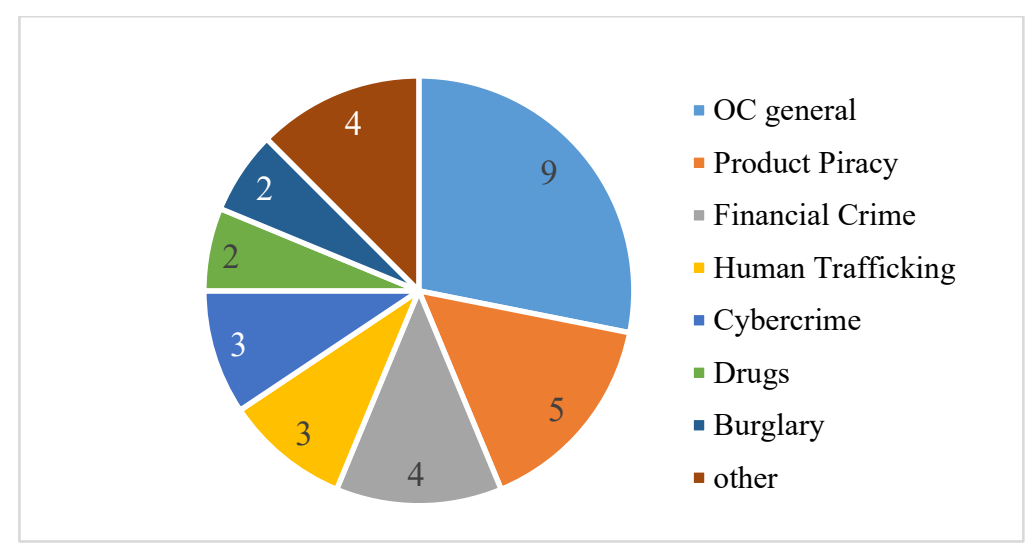

* Started, continued or completed in a given year; $2017=1$ January -1 September 2017

The research projects vary greatly with respect to their thematic focus (Figure 1). Nine out of 32 projects relate to organised crime in general, five cover product piracy including fraud in connection with pharmaceuticals, four relate to financial crimes including money laundering, three projects, respectively, deal with human trafficking and cybercrime, although criminal activities on the internet are also taken into account by other projects. Two studies investigate residential burglary and four deal with other areas of crime. Among these latter four, there are two studies addressing issues that have been at the centre of public attention in recent years and investigated by Mathias Rohe and Mahmoud Jaraba (2015) in their research project commissioned by the city government of Berlin, investigated the socalled parallel justice system among Arabic Clans, where disputes are settled in a subcultural system of conflict resolution in a way that undermines the legitimate criminal justice system. The other project aimed at a comprehensive analysis of the outlaw biker scene in Germany. It was launched in 2017 by the KfN with a grant from the European Union.

The thematic focus is not necessarily indicative of the degree to which a project aims to investigate the phenomenon proper. In many cases, the 
main emphasis is on prevention and countermeasures, rather than on the description, measurement, explanation or prediction of manifestations of organised crime. The spectrum of projects is manifold with respect to how directly they are concerned with the nature and development of empirical phenomena. At one end of the spectrum is a project on the structure of illegal markets by the Max Planck Institute for the Study of Societies. In this project, prevention or policy implications were of only secondary importance. At the other end of the spectrum is the project "Securestamp" coordinated by the Fraunhofer Institute for Physical Measurement Techniques, which dealt with new technologies for the forgery-proof printing of train tickets. Between these extremes are projects that comprise individual modules with an empirical focus on organised crime phenomena. For example, the European project "ALICA RAP" (Addiction and Lifestyles in Contemporary Europe Reframing Addictions Project) which otherwise had no direct focus on organised crime, but contained a work package that dealt with the careers of drug dealers.

Projects with an empirical component draw on a broad range of data sources and mostly collect data from more than one source. The most widely used methods of data collection are expert interviews (13 projects), analysis of open sources (11 projects), analysis of police and justice data ( 8 projects), interviews with incarcerated offenders ( 4 projects), and interviews with victims of crime (4 projects). An example for an interviewbased study with a broad range of subjects is the above-mentioned study by Rohe and Jaraba on parallel justice. This study drew on interviews with 93 members of Arabic-Kurdish family clans or the Muslim communities in Berlin more generally, as well as on expert interviews with, for example, police officers, prosecutors and judges (Rohe and Jaraba, 2015, p. 31).

A large share $(75 \%)$ of the projects received grants from one of only two institutions, the European Commission (41\%) and the BMBF (34\%), both of which have a clear preference for applied research. In contrast, there was no support for research related to organised crime from institutions that otherwise play a major role in the funding of social science research in Germany, such as the German Research Foundation (DFG) and the Volkswagen Foundation. It is also remarkable that 15 out of the 32 identified projects are international in nature, including 13 multi-country projects funded by the European Commission and two German-Austrian 
projects funded in part by the BMBF. In addition, two national-level projects by the KfN received funding from the EU.

Among the numerous academic institutions that participated in research on organised crime, there are only two that stand out in quantitative terms with the KfN involved in four projects and the University of Münster involved in three. However, their importance pales in comparison to the federal police agency Bundeskriminalamt (BKA) which in varying roles and with differing units participated in a total of 13 out of the 32 projects. This includes participation in the EU-project "Cyber-OC" and coordination of the EU-funded "Research Network on Organised Crime" by the Criminalistic Institute of the BKA (Töttel, Bulanova-Hristova and Flach, 2016).

\section{Doctoral Dissertation Projects}

The 38 dissertation projects with topics relating to organised crime that were completed since 2008 do not follow a clear trend similar to the sharp increase in other research projects from 2014 onwards. If anything, there is a development in the opposite direction. 30 out of the 38 dissertations were completed by 2013, which could suggest that organised crime has become significantly less attractive as a dissertation topic in the past few years (von Lampe and Knickmeier, 2018: 41-46; Figure 2).

In contrast to the research projects reviewed above, the dissertations also differ thematically with a clear preference for one specific phenomenon (Figure 3). While only $10 \%$ (3 out of 32) of the research projects deal with human trafficking, the share is much higher with $39 \%$ (10 out of 38) among doctoral dissertations. There is no similar thematic concentration with regard to any other phenomenon. Only financial crime, including money laundering, with three ( $8 \%$ ) dissertations is noteworthy in this respect. $39 \%$ of the dissertations are not focused on specific areas of crime. This includes a number of theses that examine various aspects of the organisation of criminals, for instance, a comparative analysis of terrorist and criminal offender structures, taking the Albanian Mafia and the Jemaah Islamiyha as an example (Florack, 2010), a study of the communication between competing criminal groups (Bossert, 2010), and a study applying different structural models to organised crime in Russia (Abasov, 2016). It is also important to point out that a large share (24 out of $38 ; 63 \%$ ) of the 
completed dissertations with reference to organised crime are legal treatises, including 18 (47\%) with an exclusive focus on legal doctrine. Overall, the doctoral dissertations are mainly concerned with measures against organised crime, not with understanding the underlying empirical phenomena.

Figure 2.

Completed doctoral dissertations related to organised crime: 2008-2017*

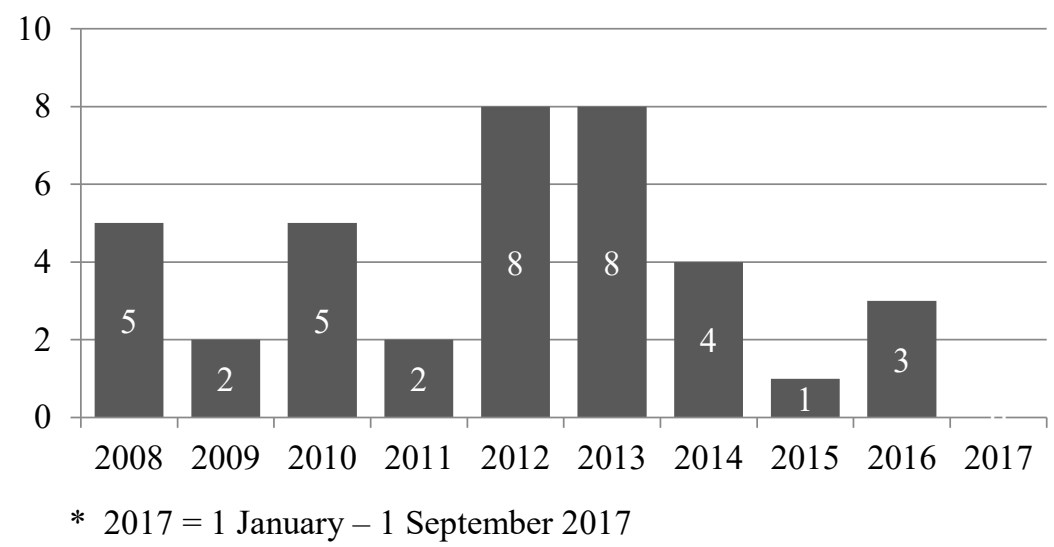

Among the doctoral dissertations that are based on empirical research, open sources are the preferred source for data (9 theses). Three dissertations include interviews with non-incarcerated offenders; three dissertations draw on interviews with victims; two dissertations are based on expert interviews; and another two dissertations conduct interviews with incarcerated offenders, including one (Filter, 2010) which investigates drug dealing inside the prison. It is remarkable that in all dissertation projects relying on field research, including the interviewing and observation of non-incarcerated offenders, the data were collected outside of Germany. This includes, for example, Annette Hübschle's (2016) study of the illegal rhino horn trade with field research carried out in Southern Africa, a region that would appear to pose much higher risks for field researchers than any part of Germany.

Another interesting difference between the doctoral dissertations and the previously discussed research projects relates to the concentration on 
specific institutions. The three universities with the highest number of organised crime related dissertations (Humboldt University Berlin: 5, Goethe University Frankfurt: 3, Cologne University: 3) otherwise do not play a prominent role in connection with research on organised crime. This creates the impression of a rather fragmented research landscape. This impression is compounded by the review of the pertinent academic publications from the time under consideration.

Figure 3.

Completed doctoral dissertations related to organised crime 2008-2017*: Thematic focus

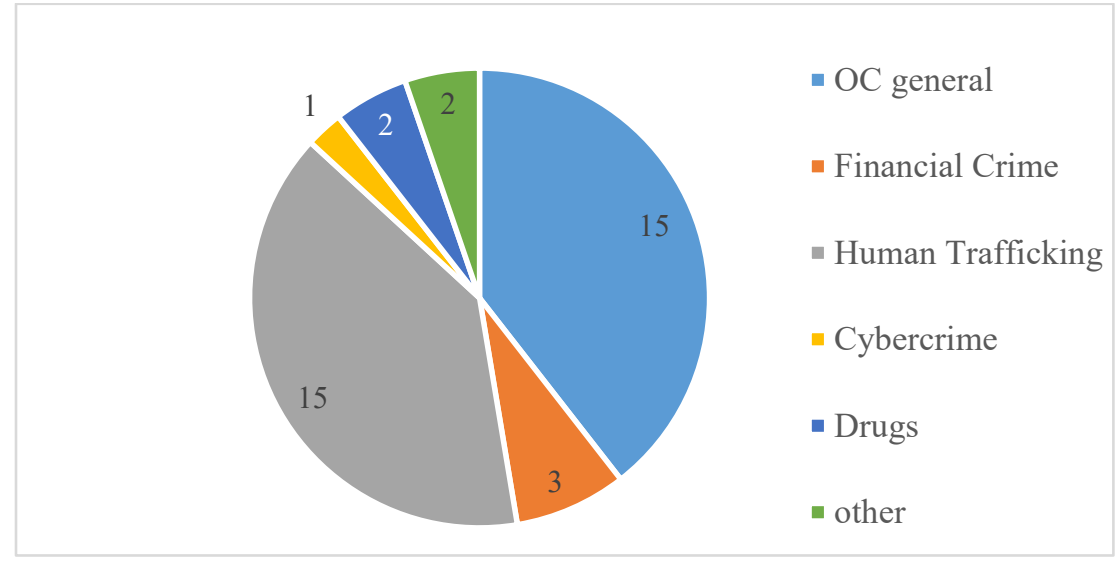

* 2017=1 January -1 September 2017

\section{Academic Publications}

215 academic publications with reference to organised crime, authored by scholars based in Germany, could be identified for the period 1 January 2008 until 1 September 2017 (von Lampe und Knickmeier, 2018: 50-69; Fig. 5). This set of publications comprises journal articles, book chapters, books (including dissertations published as books), as well as working papers published on the internet. Anthologies (co-)edited by scholars based in Germany were not included as such, but only the pertinent individual chapters contained therein. Seminar papers, bachelor theses and master theses were not included in the analysis, even if they were available on the internet. 
At times it proved difficult to decide if a publication was academic. For the purpose of the present analysis, publications were classified as academic when they were written with scholarly aspirations and in scholarly form by academics for an academic audience. When in doubt, these criteria were applied rather leniently and not in the sense of quality standards. Consequently, some poorly researched and written academic papers were included, while highly informative publications authored, for example, by journalists or by active or retired police officers based on their investigative work, were not.

Figure 4.

Academic publications relating to organised crime, 2008-2017*

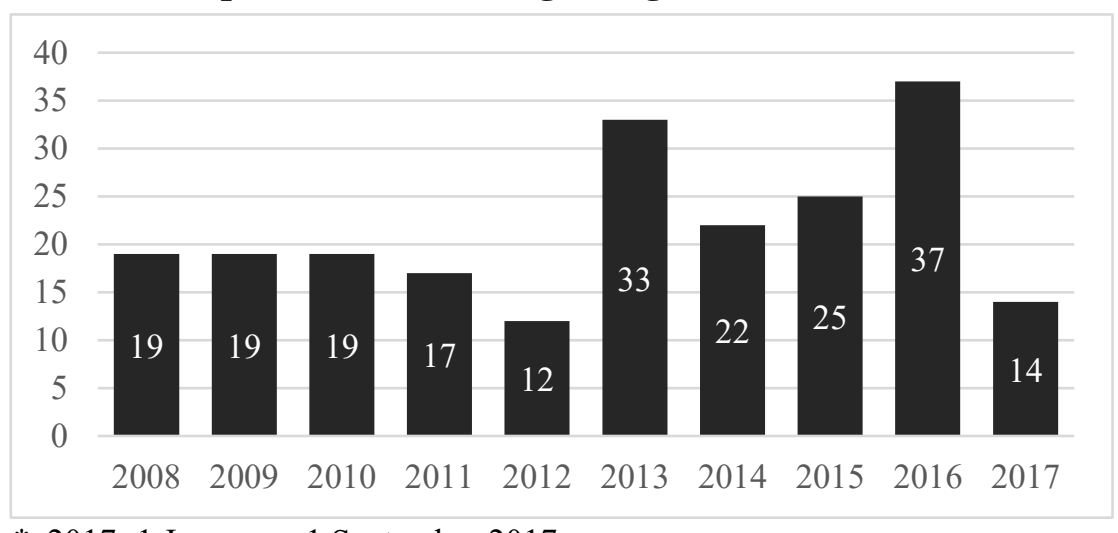

* 2017=1 January -1 September 2017

The classification of a publication as academic does not imply that it is based on original empirical research. Only a relatively small portion $(22 \%)$ of the identified publications fall in this category. $17 \%$ of the publications are legal treatises and another $6 \%$ can be classified as theoretical works. $5 \%$ of the publications cannot be placed in a specific category. By far the largest share (50\%) of the identified academic publications qualify as review essays in a broad sense. They essentially summarise previously published material, although at times paired with novel ideas.

In quantitative terms, the academic publications follow a trend similar to that of the research projects. In both cases there is an increase in number during the second half of the study period. Whereas for the years 2008 to 2012 an average of 17 publications per year could be identified, the number 
rose to 29 for the period 2013 to 2016 (Figure 4). These numbers are somewhat skewed by edited volumes with numerous chapters relating to organised crime. For example, for the year 2016 eleven out of 37 identified publications are included in the Handbook "International Law and Transnational Organised Crime," edited by Pierre Hauck and Sven Petarske (2016).

As with the research projects, the academic publications are thematically clustered around specific areas of crime (Figure 5). About half of the publications fall into this category, including $36(16,7 \%)$ on human trafficking and $23(10,7 \%)$ on drug trafficking. Other areas of crime comprise the illegal trade in cultural artefacts $(8 ; 3,7 \%)$, cybercrime $(7 ; 3,3 \%)$, environmental crime $(6 ; 2,8 \%)$ and product piracy $(5 ; 2,3 \%)$. 56 (26\%) publications are broad in scope and address organised crime in a general sense. Another 20 (9,3\%) publications deal specifically with transnational organised crime.

\section{Figure 5.}

\section{Academic publications related to organised crime} 2008-2017*: Thematic focus

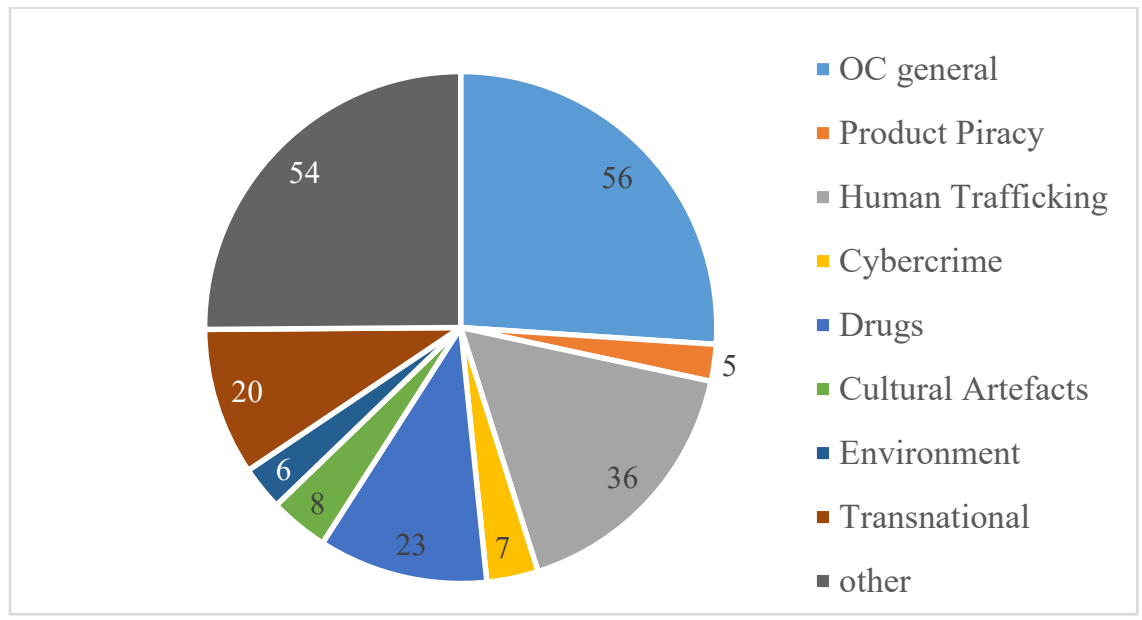

* 2017=1 January -1 September 2017

Many of the publications that are focused on specific areas of crime also raise questions regarding the organisation of criminals. However, offender structures are only rarely at the centre of attention. Apart from discussions of legal doctrine regarding the criminalisation of participation in criminal 
groups there are only a few publications that provide overviews of offender structures (Hartmann, 2009; Paul and Schwalb, 2012) or address issues of criminal organisation in abstract terms, for example with respect to the resilience of criminal networks (Lotzmann and Neumann, 2016). In addition, there is limited literature on particular offender structures. $10(4,7 \%)$ publications deal with Italian mafia-type associations. Some papers, by discussing protection racketeering by mafia organisations (see Troitzsch, 2017), could also be placed in a category of publications focusing on illegal governance.

Besides showing a preference for certain areas of crime, the 215 identified academic publications are noteworthy for their limited interest in the situation in Germany. Only 45 (21\%) focus exclusively on organised crime in Germany. Half of these 45 publications are legal treatises, where the focus on Germany results from the discussion of national law. A larger portion $(24 \%)$ of the publications deals exclusively with organised crime in countries other than Germany. The other half $(55 \%)$ address the situation in Germany and other countries or, most often, discuss organised crime at the international level.

Similar to the research projects and similar to the doctoral dissertations, the pertinent academic publications give the impression that manifestations of organised crime in Germany are of only limited interest to Germanbased scholars. Only 18 publications $(8,4 \%)$ are specifically concerned with current manifestations of organised crime within Germany and are based on original research. This includes: five works on drug trafficking; three on human trafficking; three on residential burglary; and two on outlaw biker groups. Interestingly, four out of these 18 publications are focused primarily or exclusively on crimes and criminals inside of German penitentiaries. There are no studies that seek to provide a comprehensive picture of organised crime in the tradition of the early research carried out by Hans-Jürgen Kerner (1973) and others, that would contrast and complement the annual organised crime situation reports by the BKA. Accordingly, there are only few empirical findings that would shed light on the current situation in Germany, and would permit a judgment on how organised crime has developed over the past two to three decades. Overall, the available research data do not enable a deeper understanding of offender 
structures. For example, an analysis of 2403 investigative files on residential burglaries produced no evidence of a dominance of organised groups of offenders (Dreißigacker, Baier, Wollinger and Bartsch, 2015).

With regard to outlaw biker groups it is on one hand suggested that traditional organisational structures are falling apart, while on the other hand illegal criminal activities are said to have become more widespread and more diversified in the outlaw biker subculture (Bley, 2016).

No clear picture emerges from the literature review regarding the disciplinary and institutional embeddedness of organised crime research. While the BKA, the KfN, and the University of Münster figure prominently with respect to research projects, and Humboldt University Berlin, Goethe University Frankfurt and Cologne University rank highest in the number of organised-crime related doctoral dissertations, yet other institutions have the highest output of pertinent academic publications.

There are 226 German-based authors behind the 215 identified academic publications. They belong to a large number of academic and nonacademic institutions and represent a variety of academic disciplines, ranging from the humanities and social sciences to the natural sciences and computer science. Most authors $(178 ; 78,8 \%)$ are linked to just a single publication. This is also true for the authors of doctoral dissertations, which means that in most cases dissertations do not lead to a longer-term occupation with the topic of organised crime.

Only twelve authors $(5,6 \%)$ have produced three or more pertinent publications, with Michael Müller-Karpe, a researcher at the Romano-German Central Museum in Mainz, and Arndt Sinn, a law professor at the University of Osnabrück, taking the lead with six publications each. The twelve most productive authors account for 49 of the 215 publications, which represents a share of $22,8 \%$. To put these numbers into perspective, Edward Kleemans, one of the leading Dutch organised crime scholars, authored or co-authored 50 publications relating to organised crime within the same time period.

Two of the most productive German-based authors, Martin Neumann and Klaus G. Troitzsch, have participated in the EU-project "GLODERS" at the University of Koblenz, which resulted in a number of journal articles and book chapters. Two other authors, Daniel Brombacher and Judith Vorrath, have been affiliated with the German Institute for International and 
Security Affairs in Berlin. The remaining authors with at least three pertinent publications have not been clustered at one institution.

Interestingly, among the twelve authors with the highest output there are only two criminologists, even though it has to be considered that the classification as criminologist is not always obvious given the typical incorporation of criminology into law faculties. In addition to the two criminologists there are three legal scholars, three political scientists, three sociologists and with Michael Müller-Karpe one archaeologist.

\section{Discussion and conclusion}

From the review of pertinent research projects, doctoral dissertations, and academic publications emerges no coherent picture of the landscape of organised crime research in Germany. The topic of organised crime seems to have gained some degree of popularity, but it is remaining unclear how sustained the scholarly interest really is. While institutionally based research projects and publications show a more or less pronounced numeric upward trend between 2008 and 2017, the attractiveness of organised crime related issues for dissertation projects seems to have declined in recent years. The thematic focus tends to lie on specific criminal activities, such as human trafficking, whereas offender structures only receive limited attention, and illegal governance is hardly ever an object of study. Moreover, there is a certain preference for the study of organised crime phenomena in countries other than Germany. This is especially true for studies including field research. At the same time, there is little tangible interest in those manifestations of organised crime that have been at the centre of public attention in Germany, such as the so-called Arabic Clans, outlaw biker groups, and phenomena such as organised residential burglary. To what extent recently launched studies into these thematic areas will lead to more than just sporadic, short-lived research efforts remains to be seen.

Overall, there is a striking discrepancy between a relatively large number of pertinent publications and the scarcity of empirical research. The existing research also appears to be highly insular. On one hand, there are no studies in the tradition of the comprehensive analyses of the situation of organised crime produced in earlier decades. The annual organised crime situation reports prepared by the BKA are no appropriate replacement even 
though they do have their value. What would be needed is a regular indepth assessment of the situation, perhaps along the lines of the "Monitor georganiseerde criminaliteit" in the Netherlands (Kleemans, 2014).

On the other hand, studies seldom build on each other, and thus contribute little to a cumulative body of knowledge. Without having examined the staffing of projects in any detail, a severe problem seems to be that in particular funded research tends to involve researchers that are only hired for a specific project. They naturally have little time to immerse themselves in the relevant scholarly literature and move on to other subject matters at the conclusion of a project without being able to appropriately digest and disseminate findings.

A major reason for the scarcity of empirical research arguably lies in the politics of research funding. Most of the available grants are earmarked for applied science, not for basic research. This means, first of all, that projects have to operate on the basis of untested and quite likely unfounded assumptions about the nature and dynamics of organised crime phenomena, unless insights from international research are applicable and, importantly, taken into consideration. The lack of funding for basic research also means that scholars based in Germany have relatively little to contribute to the international academic literature and to the debates centred on essential research questions regarding the nature and dynamics of organised crime. This does not necessarily mean that organised crime research in Germany is internationally isolated. There are numerous links between the German and the international research landscape. This is evidenced by the large share of international research projects and by the fact that about one third of the pertinent academic publications by German-based authors are English-language publications. However, scholars based in Germany are obviously under-represented in the international scholarly debate on organised crime. This becomes apparent in a review of the programs of major criminological conferences where international organised crime scholars congregate with little participation from Germany, and from a review of international journals that have a thematic focus on organised crime, where likewise contributions from scholars based in Germany are rare.

The main problem for organised crime research in Germany arguably lies in the fact that institutional embeddedness is weak and fragmented. Although some academic institutions make valuable contributions to the 198 
study of organised crime, there are no true centres of organised crime research with a more or less continuous flow of research projects, doctoral dissertations and academic publications. This may have to do with the interdisciplinary nature of the study of organised crime which makes integration into existing academic structures difficult and puts organised crime researchers in a disadvantage when it comes to applying for research grants and advancing one's academic career. Arguably, there is also a lack of political will to take organised crime seriously as an object of study when it comes to the weak institutional support for organised crime researchers.

A better institutionalisation of the study of organised crime would have a number of advantages. Having one or even several research centres in Germany would ensure greater continuity in the study of organised crime, which in turn would facilitate the networking among researchers in Germany and abroad, and it would make it easier for researchers in Germany to establish links to law enforcement agencies and also to victim populations, NGOs and into criminal milieus for better data access. Reliable access to data, in turn, is of course the key to obtaining funding for empirical research and to being able to participate in international projects that involve the coordinated collection and analysis of data.

\section{References}

Abasov, R., Organisierte Kriminalität in Russland: Entwicklung und wissenschaftliche Erfassung vor dem Hintergrund unterschiedlicher Strukturmodelle. Baden-Baden: Nomos, 2016.

Adelsberger, F., Kriminalität von Rockern im Land Brandenburg. Kriminalistik, 2012, 66(10), 569-576.

Backes, L., M. Bartsch, M. Baumgärtner, J. Diehl, J. Jüttner, C. Neumann, J. Schindler, A. Ulrich, W. Wiedmann-Schmidt, Nicht zu fassen. Der Spiegel, 2016, Nr. 21, 12-21.

Bader, J., Outlaw Motorcycle Clubs. Kriminalistik, 2011, 65(4), 227-234.

Behr, H.-G., Organisiertes Verbrechen. Frankfurt am Main: Ullstein, 1987. 
Berg, A., Maaßen, H.-G., Wirtschaftsschutz in der digitalen Welt. Bitkom, 2017.

https:/www.bitkom.org/sites/default/files/pdf/Presse/Anhaenge-anPIs/2017/07-Juli/Bitkom-Charts-Wirtschaftsschutz-in-der-digitalenWelt-21-07-2017.pdf (last accessed 7 February 2019)

Bley, R., Strukturen und Entwicklungen im kriminellen Rockermilieu. der kriminalist, 2016, 48(10), 26-31.

Bossert, O., Die Kommunikation konkurrierender Gruppierungen der organisierten Kriminalität. Frankfurt am Main: Verlag für Polizeiwissenschaft, 2010.

Bundeskriminalamt. Rauschgiftkriminalität: Bundeslagebild 2015. Wiesbaden: BKA, 2016.

Bundeskriminalamt. Kfz-Kriminalität: Bundeslagebild 2016. Wiesbaden: BKA, 2017.

Bundeskriminalamt. Organisierte Kriminalität: Bundeslagebild 2017. Wiesbaden: BKA, 2018.

Bundesregierung. Antwort der Bundesregierung auf die Kleine Anfrage der Abgeordneten Irene Mihalic, Dr. Gerhard Schick, Volker Beck (Köln), weiterer Abgeordneter und der Fraktion BÜNDNIS 90/DIE GRÜNEN: Entwicklung der italienischen Mafiakriminalität in Deutschland seit dem Mordanschlag von Duisburg 2007. Deutscher Bundestag Drucksache 18/13320, 15.08.2017.

Bülles, E. Deutschland Verbrecherland? Mein Einsatz gegen die organisierte Kriminalität. Berlin: Econ, 2013.

Dowideit, A. Das Netz der Pflegemafia. Die Welt, 30 May 2017, p. 9.

Dreißigacker, A., D. Baier, G.R. Wollinger und T. Bartsch, Die Täter des Wohnungseinbruchs: Sind es die „Osteuropäer“, die „professionellen Banden“ oder die „Drogenabhängigen“? Kriminalistik, 2015, 69(5), 307-311.

EMCDDA. Europäischer Drogenbericht: Trends und Entwicklungen. Luxemburg: Amt für Veröffentlichungen der Europäischen Union, 2017.

Europol. EU Drug Markets Report: A Strategic Analysis. The Hague: Europol, 2013.

Filter, I. Beschaffung, Handel und Konsum illegaler Drogen im Strafvollzug: Eine Situationsanalyse. Doctoral dissertation. Universität Bremen, 2010. 
Florack, N. Transnationale kriminelle und terroristische Netzwerke: ein Vergleich der Netzwerkstruktur der albanischen Mafia mit der Jemaah Islamiyah. Berlin: Köster, 2010.

Ghadban, R. Arabische Clans: Die unterschätzte Gefahr. Berlin: Econ, 2018.

Gögelein, M. Taschendiebstahl-Lappalie oder schwere Kriminalität? Kriminalistik, 2017, 71(2), 129-136.

Gülay, C., Kuhn, H., Türken-Sam: Eine deutsche Gangsterkarriere. München: Deutscher Taschenbuch Verlag, 2009.

Hartmann, A., Delinquenz in der Gruppe. In: H.-L. Kröber, D. Dölling, N. Leygraf, H. Sass (eds.), Handbuch der Forensischen Psychiatrie (pp. 209-235). Frankfurt am Main: Steinkopff, 2009.

Hauck, P., S. Petarske, (eds.), International Law and Transnational Organised Crime. Oxford: Oxford University Press, 2016.

Henninger, M., 'Importierte Kriminalität' und deren Etablierung. Kriminalistik, 2002, 56(12), 714-729.

Henninger, M., T. Susebach, Die Berliner "Türsteherszene". Kriminalistik, 2005, 59(7), 395-407.

Hübschle, A., A game of horns: transnational flows of rhino horn. Cologne: International Max Planck Research School on the Social and Political Constitution of the Economy, 2016.

Jäger, S., Strategische Aspekte der Bekämpfung der Rockerkriminalität. Kriminalistik, 2012, 66(8-9), 495-501.

Kamstra, S., Berlin im Griff der OK? der kriminalist, 2014, 46(7-8), 1826.

Kerner, H.-J., Professionelles und organisiertes Verbrechen. Wiesbaden: Bundeskriminalamt, 1973.

Kleemans, E., Organised crime research: challenging assumptions and informing policy. In: E. Cockbain and J. Knutsson (eds.), Applied Police Research: Challenges and Opportunities (pp. 57-67). New York: Routledge, 2014.

KPMG, Project Sun: A study of the illicit cigarette market in the European Union, Norway and Switzerland. 2017

https://assets.kpmg.com/content/dam/kpmg/uk/pdf/2017/07/projectsun-2017-report.pdf (last accessed 15 September 2017)

Lotzmann, U. and M. Neumann, A simulation model of intra-organisational conflict regulation in the crime world. In: C. Elsenbroich, D. 
Anzola and N. Gilbert (eds.), Social dimensions of organised crime: modelling the dynamics of extortion rackets. (pp. 177-213). Cham: Springer, 2016.

Mack, J., H-J. Kerner, The crime industry. Westmead: Saxon House, 1975. Paul, A. and B. Schwalb, Kriminelle Organisationen. In: M. Apelt and V. Tacke (eds.), Handbuch Organisationstypen (pp. 327-344). Wiesbaden: Springer VS, 2012.

Paulus, M., Ignoriert, toleriert und verkannt? Die albanische Mafia im bundesdeutschen Rotlichtmilieu. der Kriminalist, 2015, 47(2), 18-25.

Rebscher, E. and W. Vahlenkamp, Organisierte Kriminalität in der Bundesrepublik Deutschland. Wiesbaden: Bundeskriminalamt, 1988.

Rohe, M. and M. Jaraba, Paralleljustiz: Eine Studie im Auftrag des Landes Berlin, vertreten durch die Senatsverwaltung für Justiz und Verbraucherschutz. 2015.

https://www.berlin.de/sen/justva/_assets/gesamtstudie-paralleljustiz.pdf (last accessed 12 September 2017)

Schulz, A., Rocker, Mafia, Geldwäscher - Deutschland fest im Griff der Organisierten Kriminalität? der kriminalist, 2012, 44(3), 13-15.

Töttel, U., G. Bulanova-Hristova and G. Flach (eds.), Research Conferences on Organised Crime at the Bundeskriminalamt in Germany, Vol. III, Transnational Organised Crime, 2013-2015. Wiesbaden: Bundeskriminalamt, 2016.

Troitzsch, K., Can agent-based simulation models replicate organised crime? Trends in Organised Crime, 2017, 20(1-2), 100-119.

Varese, F., Mafias on the move. Princeton: Princeton University Press, 2011.

von Lampe, K., Measuring organised crime: A critique of current approaches. In: P. van Duyne, M. Jager, K. von Lampe, J. Newell (eds.), Threats and phantoms of organised crime, corruption and terrorism: Critical European perspectives (pp. 85-116). Nijmegen, the Netherlands: Wolf Legal Publishers, 2004.

von Lampe, K. and S. Knickmeier, Organisierte Kriminalität: Die aktuelle Forschung in Deutschland. Schriftenreihe Forschungsforum Öffentliche Sicherheit, no. 24. Berlin: Freie Universität Berlin, 2018.

Weschke, E. and K. Heine-Heiß, Organisierte Kriminalität als Netzstrukturkriminalität Teil 1. Berlin: Fachhochschule für Verwaltung und Rechtspflege, 1990. 
Winter, M., Osteuropäische Einbrecherbanden auf Beutezug durch die Republik. Kriminalistik, 2015, 69(10), 572-575.

Wöhrle, C., Ehrenwerte Familien: Libanesische Clans in Deutschland. Focus , 2017, 16, 24 April.

Ziercke, J., Aktuelles Lagebild und Entwicklung der Gewaltkriminalität. Kriminalistik, 2010, 64(12), 697-703. 